\title{
Antioxidant and Alpha Glucosidase Inhibitor Screening of Merremia peltata L. as Potential Traditional Treatment for Diabetes Mellitus
}

\author{
Bannan Muthi'atul Af-idah ${ }^{1}$, Muhammad Hanafi ${ }^{2}$, Berna Elya ${ }^{1, *}$
}

Bannan Muthi'atul Af-idah', Muhammad Hanafi², Berna Elya ${ }^{1, *}$

${ }^{1}$ Faculty of Pharmacy, Universitas Indonesia, Kampus UI Depok, INDONESIA.

IIndonesian Institute of Sciences and Faculty of Pharmacy, University of Pancasila, INDONESIA.

\section{Correspondence}

Berna Elya

Professor and Lecturer at the Faculty of Pharmacy, Universitas Indonesia, INDONESIA.

E-mail: berna.elya@farmasi.ui.ac.id

History

- Submission Date: 27-01-2021;

- Review completed: 28-03-2021;

- Accepted Date: 03-05-2021.

DOI : 10.5530/pj.2021.13.116

Article Available online http://www.phcogj.com/v13/i4

Copyright

(C) 2021 Phcogj.Com. This is an openaccess article distributed under the terms of the Creative Commons Attribution 4.0 International license.

\begin{abstract}
Introduction: Merremia peltata is ethnomedicine plant used as traditional medicine in Sulawesi, Sumatra, Maluku and Papua. M. peltata is used for diabetic. Diabetes mellitus therapy with inhibit activity of alpha glucosidase enzyme could delay absorption of monosaccharides after a meal and interrupt glucose transport into the circulation. Objective: This research purpose is to investigate in vitro antioxidant activity and alpha glucosidase enzyme inhibitor leaves and stem extract of M. peltata. Method: The Stem and leaves of $M$. peltata were extracted sequentially using the UAE method using hexane, ethyl acetate, and methanol as mobile phase/solvent. The M. peltata extracts were subjected to the antioxidant activity assay by the DPPH radical scavenging and FRAP method. Antidiabetic activity was determined by an enzymatic alpha glucosidase inhibitor. Result: The extract which had best performance in antioxidant activity was stem ME with value of IC50 in DPPH $47.41 \mu \mathrm{g} / \mathrm{mL}$ and total antioxidant power 340.04 $\mu \mathrm{mol} / \mathrm{g}$. This study showed that leaves and stem extract of $M$.peltata have potential alpha glucosidase inhibitors for diabetic therapy. Stem ME had the best activity with IC50 value 47.44 $\mu \mathrm{g} / \mathrm{mL}$, almost two times better than acarbose as a positive control (IC50 $=98.38 \mu \mathrm{g} / \mathrm{mL}$ ). Leaves ME, leaves EA, and stem EA also give better activity of alpha glucosidase inhibitors than acarbose with IC50 value $67.24 \mu \mathrm{g} / \mathrm{mL}, 69.38 \mu \mathrm{g} / \mathrm{mL}$, and $72.85 \mu \mathrm{g} / \mathrm{mL}$, respectively. Conclusion: $M$. peltata has potential antioxidant and alpha glucosidase inhibitor activity for diabetic therapy.

Key words: Merremia peltata, Antidiabetic, Alpha-glucosidase inhibitor, Antioxidant.
\end{abstract}

\section{INTRODUCTION}

Diabetes mellitus is a metabolic disorder that is marked by the rise in blood sugar due to a decrease in insulin secretion by pancreatic beta cells and insulin function or disorder ${ }^{1}$. World Health Organization (WHO) estimates 422 million adults over the age of 18 lived with diabetes globally in 2014 and caused 1.5 million deaths in $2012^{2}$. The whole world diabetes mellitus prevalence increases continuously and predicted in 2030 people with diabetes mellitus will reach 550 million people, this is equivalent to about three new cases every 10 seconds, or nearly 10 million per year ${ }^{3}$.

One of the therapies used in the treatment of diabetes is alpha glucosidase inhibitor (eg: Acarbose, Miglitor, and Voglibose) $)^{1}$. Acarbose is Food and Drug Administration (FDA) approved for the treatment of adults with type 2 diabetes mellitus. Acarbose is a complex oligosaccharide that acts as a competitive, reversible inhibitor of pancreatic alpha amylase and membrane-bound intestinal alpha glucosidase enzymes. The enzyme breaks down oligosaccharides, trisaccharides, and disaccharides (sucrose, maltose) to monosaccharides (glucose, fructose) in the brush border of the small intestine, so the absorption of monosaccharides after a meal is delayed and transport through the mucosal surfaces into the circulation is interrupted ${ }^{4}$. Unfortunately, there are some side effects of acarbose therapy, like flatulence, diarrhea, and abdominal pain causing uncomfortable to patients ${ }^{5}$.

Indonesia has so many biodiversity consisting of more than 40.000 endemic plants, and 7000 among them reported as medical plants 6 . More than 400 plants have reported as hypoglycemic agent with various mechanism. the plant has some bioactive constituent such as components, phenolics, glycosides, alkaloids, terpenoids, flavonoids ${ }^{7}$. Traditional medicines have been used for a long time and play an important role as alternative medicines. Using herbal medicine prove has less side effects and more acceptable in the Indonesian society also in diabetic therapy. Since ancient times, the ancestors of the Indonesian people have used plants to maintain health and treat various diseases, called "Jamu". Jamu is a traditional herb that can be made from plants, animals, minerals, preparations (galenic) or a mixture of these ingredients, which have been used from generation to generation for treatment based on experience ${ }^{8}$.

Merremia peltata (L.) Merr.) is perennial herbaceous vine from Convolvulaceae family, which often wrapped around the other plants. M. peltata known as "Aka Lambuang" is an ethnobotanical plant used

Cite this article: Afidah, Muthiatul B, Elya B, Hanafi M. Antioxidant and Alpha Glucosidase Inhibitor Screening of Merremia peltata L. as Potential Traditional Treatment for Diabetes Mellitus. Pharmacogn J. 2021;13(4):902-908. 
as traditional medicine in Sulawesi, Sumatra, Maluku and Papua. Phytochemical screening showed that leaves extract of $M$. peltata contains terpenoid, steroid, saponin, and phenolic ${ }^{9}$. Traditionally, $M$. peltata is used as a potion for inflammation, abdominal pain, wound healing, infectious disease, diabetic therapy ${ }^{10}$. Despite of M. peltata is used traditionally as diabetic therapy, antidiabetic activity of $M$. peltata has not been investigated.

Previous in vitro and in vivo studies showed that some plants from merremia genus have antidiabetic activity. Plants in the merremia genus are reported to contain phenolic compounds, flavonoids, sulfates, aliphatic pyrrolidine amides, tropane, and alkaloid ${ }^{11}$. In vitro study showed that leaves ethanol extract of Merremia hederacea and hexane fraction of Merremia mammosa had inhibitor activity of enzyme alpha amylase and alpha glucosidase ${ }^{6,11}$. In vivo study using streptozotocin induced diabetic rats showed extract etanol of Merremia tridentata, Merremia mammosa, Merremia emarginata, and Merremia hederacea have potential antidiabetic activity ${ }^{11,12,13,814}$. Based on the chemotaxonomy of chemical compounds in the same genus, $M$. peltata has the possibility of having the same pharmacological activity as alpha glucosidase inhibitor for potential antidiabetic agent, but such tests have not been conducted. This research purpose is to investigate in vitro antioxidant activity and alpha glucosidase enzym inhibitor of leaves and stem extract of M. peltata.

\section{MATERIAL AND METHOD}

\section{Plant material}

Samples used in this study were the bark and leaves of M. peltata which obtained from Ratatotok district, North Sulawesi and identified by Herbarium Bogoriensis, Biological Research Centre, Indonesian Institute of Science.

\section{Chemical}

Chemicals used in this study were Phosphate buffer $\mathrm{pH}$ 7, Alphaglucosidase (Wako Pure Chemical Industries Ltd., Japan), Acarbose, ethanol, ethyl acetate, methanol, n-hexane, para nitrophenyl alphaD-glucopyranoside (Wako Pure Chemical Industries Ltd. EC 3.2.1.20, Jepang), dichloromethane, dimethyl sulphoxide (Merck cat. 3.17275, Germany),Sodium carbonate (Merck cat. 1.09940, Germany), 1.1-diphenyl-2-picrylhidrazyl (DPPH), ascorbic acid (Sigma-Aldrich, A5960), Ferrous sulfate heptahydrate (MERCK, Germany).

\section{Sample preparation}

Fresh Stem and leaves of $M$. peltata were washed using fresh water and dried in the oven, then crushed with a grinder to get powder simplisia.

\section{Extraction}

The dried powder of stem and leaves $M$. peltata were extracted sequentially using Ultrasonic Assisted Extraction (UAE). The sample $(100 \mathrm{~g})$ extracted using $\mathrm{N}-\mathrm{Heksan}(\mathrm{NH})(500 \mathrm{ml})$ for 30 minutes three times, then filtered to obtain filtrate and residue. The residue was dried and then re-extracted using Ethyl Acetate (EA) then Methanol (ME) using the same method. The filtrate was evaporated using a rotary evaporator to obtain crude extract.

\section{Microscopic observation by light and SEM microscope}

The microscopic part of dried powder of $M$. peltata leaves and stem were observed using light and Scanning Electron Microscope (SEM) microscope.

\section{Antioxidant assay by DPPH inhibition}

The antioxidant ability of extract was determined using (1.1-diphenyl2-picrylhidrazyl) DPPH radical scavenging activity method described by Burda \& Oleszek (2001) with slight modification. Ascorbic acid was used for positive control. Five milligram extracts were dissolved in 10 $\mathrm{ml}$ methanol solution, and diluted to get sample concentrations 20,40 , 60, 80, and 100 ppm. $500 \mu \mathrm{L}$ sample solution were added into $1.5 \mathrm{~mL}$ DPPH solution, mixed for 2 minutes, and incubated in dark room for 30 minutes. After incubation, the sample absorbance was measured using Spectrophotometer UV-Vis in $517 \mathrm{~nm}$. The color change from purple to yellow means free radical scavenging efficiency ${ }^{15}$. Free radical scavenging activity was calculated as the percentages of color decreasing of DPPH solution using the following equation:

Free radical scavenging activity $(\%)=1-\frac{\text { sample absorbance }}{\text { control absorbance }} \times 100$

Antioxidant assay by (Ferric Reducing Antioxidant Power) FRAP

The total antioxidant potential of stem and leaves M. peltata determined using the method described by Wojdylo et al (2007) with slight modification. The FRAP reagent was made with a mixture of TPTZ (2,4,6-tripyridyl-s-triazine) $10 \mathrm{mM}$ in $40 \mathrm{mM} 40 \mathrm{HCl}, \mathrm{FeCl} 3.6 \mathrm{H} 2 \mathrm{O}$ $(20 \mathrm{mM})$ and Acetate buffer $(300 \mathrm{mM}, \mathrm{pH} 3.6)$ in the ratio 1:1:10. Extract sample $(100 \mu \mathrm{g} / \mathrm{ml})$ was mixed with $3 \mathrm{~mL}$ FRAP reagent then the absorbance was measured after $10 \mathrm{~min}$. Ascorbate acid was used as positive control. The calibration curve prepared using $\mathrm{FeSO} 4.7 \mathrm{H} 2 \mathrm{O}$ methanol solution in concentration 100 to $2000 \mathrm{mM}$ and measured concentration of $\mathrm{Fe} 2+$ at $593 \mathrm{~nm}$ using Spectrophotometer UV-Vis. The amount of $\mathrm{Fe} 2+$ produced from the reduction of $\mathrm{Fe} 3+$ by the extract was calculated from the standart curve prepared from ferrous sulphate solution and results were expressed as mg Fe2+ / 100 g dry sample. All determinations were performed in triplicate ${ }^{16}$.

\section{Alpha glucosidase inhibitor activity assay}

The alpha glucosidase inhibitor was determined using adapted published protocol from Elya et al (2015). Acarbose used as a positive control. Extract of stem and leaves $M$. peltata were dissolved in maximum $10 \%$ DMSO and phosphate buffer solution $\mathrm{pH}$ 6.8. Five various concentrations of sample and acarbose were made to determine IC50 of alpha glucosidase inhibitor. Thirty microliter of sample, $36 \mu \mathrm{L}$ of phosphate buffer solution, and $17 \mu \mathrm{L}$ PNPG substrate at concentration of $4 \mathrm{mM}$ were put in 96 well microplate. The mixture was incubated at $37^{\circ} \mathrm{C}$ for $5 \mathrm{~min}$. After incubation, $17 \mu \mathrm{L}$ of alpha glucosidase enzyme solution $0.025 \mathrm{U} / \mathrm{ml}$ was added into each well. The mixture was incubated at $37^{\circ} \mathrm{C}$ for $15 \mathrm{~min}$. The reaction was stopped by adding $100 \mu \mathrm{L}$ of Sodium Carbonate (Na2CO3) $200 \mathrm{mM}$. Absorbance was measured at $405 \mathrm{~nm}$ using a microplate reader ${ }^{17}$. Each test was repeated three times.

Percent inhibition of the sample was determined using following equation:

Inhibition $(\%)=\frac{(A 1-A 2)}{A 1} \times 100$

Where:

$\begin{array}{lll}\text { A1 } & : & \begin{array}{l}\text { Absorbance of blanko }\left(\mathrm{B}^{*}\right)-\text { control of blanko }\left(\mathrm{KB}^{* *}\right) \\ \text { A2 }\end{array} \quad: \begin{array}{l}\text { Absorbance of sample }(\mathrm{S}) \text { - control of sample } \\ \text { absorbance }\left(\mathrm{KS}^{* * *}\right)\end{array} \\ * & : \quad \begin{array}{l}\text { Blanko contains substrate }+ \text { enzyme, without extract } \\ * *\end{array} & : \begin{array}{l}\text { Control of blanko contains substrate and buffer, without } \\ \text { enzyme and extract }\end{array} \\ * * * \quad & : \begin{array}{l}\text { Control of sample contains substrate + extract with the } \\ \text { addition of the enzyme after incubation }\end{array}\end{array}$

Percent inhibition obtained in each sample was processed in the form of a graph, which $\mathrm{x}$ as concentration and $\mathrm{y}$ as percent inhibition of sample to get linear regression equation $\mathrm{Y}=\mathrm{ax}+\mathrm{b}$. The Inhibition Concentration (IC50) was determined using following equation: 
IC50 $=\frac{(50-a)}{b}$

\section{RESULT AND DISCUSSION}

\section{Extraction}

Five hundred gram dried powder of stem and leaves of $M$. peltata were extracted using UAE method. The ultrasonic extraction method was faster and more effective to extract secondary metabolites from plants than conventional methods like maceration or soxhletation ${ }^{18}$. The high power ultrasound $(20 \mathrm{t} 025 \mathrm{kHz})$ could degrade the cell wall and increase the penetration of solvent through the plant cells, enhancing the solubility of phytochemicals.

Extraction was carried out sequentially with different polarity solvent to maximize solubility of phytochemical from the sample, with increasing polarity solvent starting from N-Hexane (NH), Ethyl Acetate (EA), then Methanol (ME). Solvent polarity would affect the type and amount of chemical compounds to be extracted, the antioxidant capacity, and biological activity of the extract ${ }^{19}$. The yield of UAE sequential extraction was displayed in the following table 1 . Table 1 showed that $\mathrm{NH}$ extract from stem and leaves had the highest amount indicating that the sample contained more non polar than polar substituents.

\section{Antioxidant assay by DPPH inhibition}

Antioxidant assay using (DPPH) free radical scavenging method was the first approach for evaluating the antioxidant potential of a compound, developed by Blois $(1958)^{20}$. A stable free radical $\alpha$, a-diphenyl- $\beta$-picrylhydrazyl (DPPH; C18H12N5O6, M=394.33) had odd electron of nitrogen atom. An antioxidant compound donated a hydrogen atom formed hydrogen bond with nitrogen atom in DPPH, marked with decolorization of violet DPPH solution turned to yellow. The absorbance of DPPH at $517 \mathrm{~nm}$ was interrupted by light, oxygen, $\mathrm{pH}$, and type of solvent in addition to the antioxidant. Polar solvent may decrease the odd electron density of nitrogen atoms in DPPH and increase the reactivity of DPPH. DPPH in methanol solution had good stability under the light. Incubation under dark room was needed to prevent photochemical decomposition of DPPH that positively correlated with the absorbed light energy ${ }^{21}$

Ascorbic acid (AA) was used as a positive control because of its strong antioxidant properties. AA acts primarily as a donor of single hydrogen atoms, and the radical anion monodehydroascorbate reacts mainly with radicals. Together these properties account for the remarkable antioxidant actions of ascorbic acid ${ }^{22}$.

IC50 is the concentration of compounds that have $50 \%$ inhibition of $\mathrm{DPPH}$. The compound with higher antioxidant activity will have the lower value of IC50. According to Phongpaichit et al (2007), a compound stated as free antiradical very strong when the IC50 value $<10 \mu \mathrm{g} / \mathrm{mL}$, strong if the IC50 value is between $10-50 \mu \mathrm{g} / \mathrm{mL}$, moderate if the IC50 value ranges from $50-100 \mu \mathrm{g} / \mathrm{mL}$, weak when the IC50 value is between $100-250 \mu \mathrm{g} / \mathrm{mL}$ and is inactive when IC50 above $250 \mu \mathrm{g} / \mathrm{mL}$. DPPH inhibition of stem and leaves $M$. peltata were showed in picture 2. IC50 obtained from a regression linear equation with plotting sample concentration in $\mathrm{x}$ axis and \% inhibition in $\mathrm{y}$ axis of graph. Regression equation and IC50 of the sample were presented in table 3.

AA as a positive control showed very strong antioxidant activity with IC50 value $10.49 \mu \mathrm{g} / \mathrm{mL}$. The stem ME showed the best antioxidant

Table 1: The yield of $M$. peltata extraction using UAE.

\begin{tabular}{|c|c|c|c|c|c|c|}
\hline & Stem NH & Stem EA & Stem ME & $\begin{array}{c}\text { Leaves } \\
\text { NH }\end{array}$ & $\begin{array}{c}\text { Leaves } \\
\text { EA }\end{array}$ & $\begin{array}{l}\text { Leaves } \\
\text { ME }\end{array}$ \\
\hline $\begin{array}{l}\text { Weight of } \\
\text { extract (g) }\end{array}$ & 20.3 & 14.7 & 13.4 & 43.4 & 32 & 28.6 \\
\hline Yield (\%) & $4.1 \%$ & $2.9 \%$ & $2.7 \%$ & $8.7 \%$ & $6.4 \%$ & $5.7 \%$ \\
\hline
\end{tabular}

Table 2: Antioxidant activity of $\boldsymbol{M}$. peltata extract using DPPH assay.

\begin{tabular}{ccccc}
\hline \multirow{2}{*}{$\begin{array}{c}\text { Sample Cons } \\
(\mu \mathrm{g} / \mathrm{mL})\end{array}$} & \multicolumn{4}{c}{ \% inhibition DPPH } \\
\cline { 2 - 5 } & $\begin{array}{c}\text { Asam } \\
\text { Ascorbat }\end{array}$ & Stem NH & Stem EA & Stem ME \\
\hline Regression & $\mathrm{y}=0.3788 \mathrm{x}+$ & $\mathrm{y}=0.4824 \mathrm{x}+$ & $\mathrm{y}=0.5847 \mathrm{x}+$ & $\mathrm{y}=0.7291 \mathrm{x}+$ \\
Eq. & 46.026 & 1.9886 & 4.2386 & 15.436 \\
$\mathrm{IC} 50(\mu \mathrm{g} / \mathrm{mL})$ & 10.49 & 99.53 & 81.94 & 47.37 \\
\hline
\end{tabular}

\begin{tabular}{|cccc|}
\hline \multirow{2}{*}{$\begin{array}{c}\text { Sample Cons }(\mu \mathrm{g} / \\
\mathrm{mL})\end{array}$} & \multicolumn{3}{c}{ \% inhibition DPPH } \\
\cline { 2 - 4 } & Leaves NH & Leaves EA & Leaves ME \\
\hline \multirow{2}{*}{ Regression Eq. } & $\mathrm{y}=0.5028 \mathrm{x}-4.625$ & $\mathrm{y}=0.9045 \mathrm{x}-$ & $\mathrm{y}=0.6295 \mathrm{x}+$ \\
& & 17.114 & 5.8409 \\
$\mathrm{IC} 50(\mu \mathrm{g} / \mathrm{mL})$ & 108.64 & 74.20 & 70.15 \\
\hline
\end{tabular}

activity of all sample extracts with the lowest IC50 values $47.37 \mu \mathrm{g} / \mathrm{mL}$. The leaves ME, leaves EA, stem EA, and stem NH were categorized as moderate antioxidant activity with IC50 value respectively $70.15 \mu \mathrm{g} /$ $\mathrm{mL}, 74.20 \mu \mathrm{g} / \mathrm{mL}, 81.94 \mu \mathrm{g} / \mathrm{mL}$, and $99.53 \mu \mathrm{g} / \mathrm{mL}$. The Leaves NH were categorized as a weak antioxidant activity with IC50 value $108.64 \mu \mathrm{g} /$ $\mathrm{mL}$.

\section{Antioxidant assay by FRAP}

The FRAP assay is a relatively simple, quick, and inexpensive method for measuring total antioxidant activity of plant samples. The assay uses the reduction of ferric ions $(\mathrm{Fe} 3+)$ to ferrous ions $(\mathrm{Fe} 2+)$, indicated by a colour change from pale yellow color to intensive blue, and absorbance at $598 \mathrm{~nm}^{23}$. Calibration curve from ferrous sulfate heptahydrate (FSH) was made as a standart and obtained regression equation $\mathrm{y}=0.00257 \mathrm{x}+$ 0.04715 . The total antioxidant activity of the sample shown in following table 4.

Based on the FRAP assay, stem ME also had the highest total antioxidant power of the plant extract with value $207.08 \mu \mathrm{mol} / \mathrm{g}$ after ascorbic acid as a positive control antioxidant with value $340.04 \mu \mathrm{mol} / \mathrm{g}$. The stem EA, leaves ME, leaves EA, leaves $\mathrm{NH}$, and stem $\mathrm{NH}$ had total antioxidant value $164.53 \mu \mathrm{mol} / \mathrm{g}, 137.33 \mu \mathrm{mol} / \mathrm{g}, 77.37 \mu \mathrm{mol} / \mathrm{g}, 65.18$ $\mu \mathrm{mol} / \mathrm{g}$, and $59.75 \mu \mathrm{mol} / \mathrm{g}$, respectively. Methanol fraction showed good capacity of antioxidant than ethyl acetate or n-hexane because polarity of the solvent could dissolve polar compounds like polyphenol and flavonoid, that had good antioxidant activity. Wakeel et al (2019) reported polarity of the solvent affected phenolic content and flavonoid content of the extract sample, directly correlated with reducing power, antioxidant, and free radical scavenging capacity. The amount of phenolic compound, flavonoid compound and antioxidant capacity were significantly increased with increasing polarity and abruptly decreasing at a very high polarity index such as water. It means that the plants have different biochemical compounds with a range of polarity ${ }^{24}$.

\section{Alpha glucosidase inhibitor activity assay}

The principle of this test is that a substance that acts as an inhibitor will bind to the a-glucosidase enzyme so that the enzyme activity in hydrolyzing the pNPG substrate (p-nitrophenyl-a-D-glucopyranoside) becomes p-nitrophenol which is yellow in color will be inhibited. The absorbance is measured at $405 \mathrm{~nm}$ based on the amount of p-pyrophenol formed.

The in vitro alpha glucosidase inhibitor assay of the $M$. peltata stem and leaves extract used five variations of sample concentration to get a graph which $\mathrm{x}$ axis as concentration and $\mathrm{y}$ axis as percent inhibition. Regression equation from the graph used to determine IC50 of the extract. The result showed that Stem ME had the best activity with IC50 value $47.44 \mu \mathrm{g} / \mathrm{mL}$, almost two times better than acarbose as a positive 


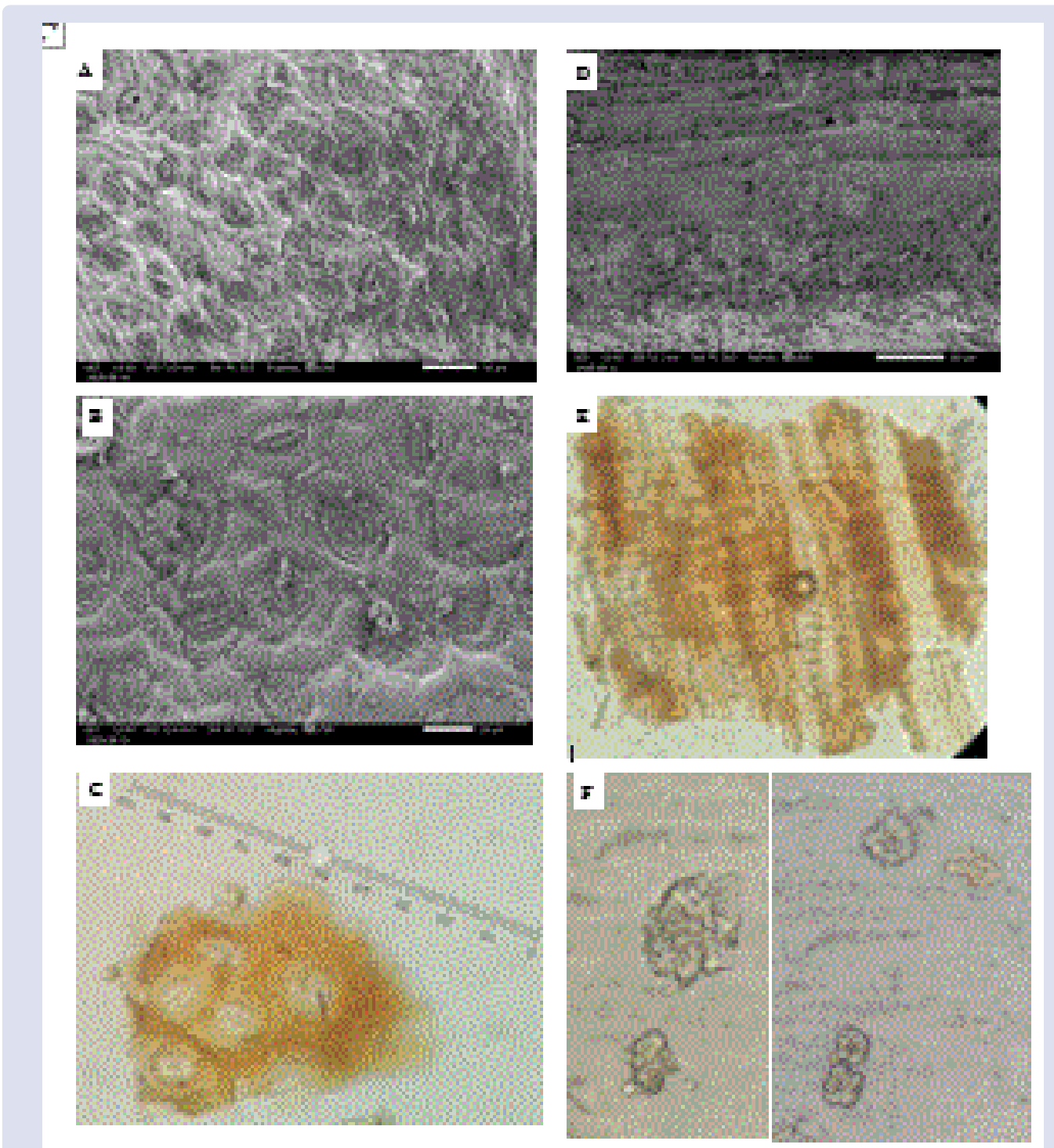

Figure 1: Microscopic observation of stem and leaf M. peltata using light microscope and SEM. Stomata of $M$. peltata leaf observed using SEM (A and B) and light microscope $\odot$. Vascular system in M.peltata stem observed using SEM (D) and light microscope (E). Calcium oxalate ( $\mathrm{CaO}$ ) found in M. peltata stem observed using light microscope (F).

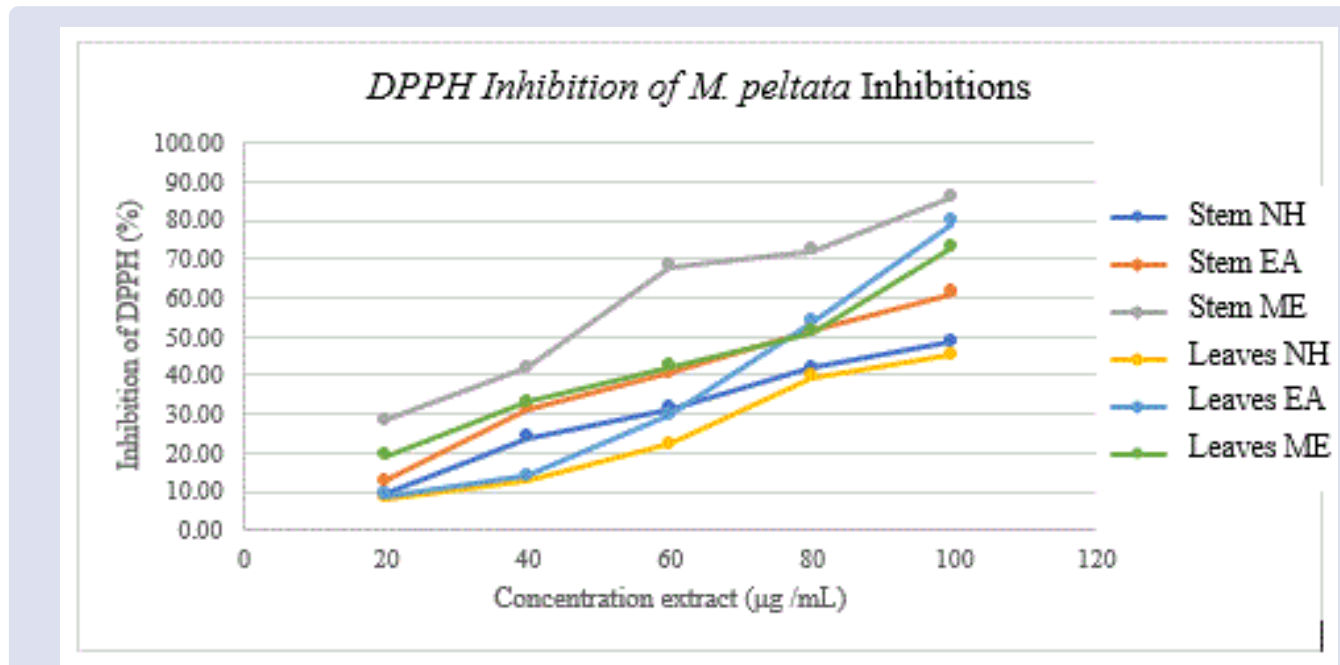

Figure 2: DPPH percent inhibitions of stem and leaves M. peltate. 
Table 3: Antioxidant power of M. peltate extract by FRAP assay.

\begin{tabular}{cc}
\hline Sample & FRAP $\left(\mu \mathrm{mol} \mathrm{Fe}{ }^{2+} / \mathrm{mg}\right)$ \\
\hline Acarbose & $340.04 \pm 3.0$ \\
Stem NH & $56.75 \pm 1.7$ \\
Stem EA & $164.53 \pm 1.3$ \\
Stem ME & $207.08 \pm 4.8$ \\
Leaves NH & $65.18 \pm 0.5$ \\
Leaves EA & $77.37 \pm 0.6$ \\
Leaves ME & $138.33 \pm 0.5$ \\
\hline
\end{tabular}

Table 4: IC50 alpha glucosidase inhibitor activity of stem and leaves $M$. peltate.

$\begin{array}{ccc}\text { Sample } & \text { Regression Equation } & \mathrm{IC5}(\mu \mathrm{g} / \mathrm{mL}) \\ \text { Acarbose } & \mathrm{y}=0.2156 \mathrm{x}+28.79 & 98.38 \\ \text { Stem NH } & \mathrm{y}=0.2775 \mathrm{x}-7.6194 & 207.64 \\ \text { Stem EA } & \mathrm{y}=0.7474 \mathrm{x}-4.4503 & 72.85 \\ \text { Stem ME } & \mathrm{y}=0.6613 \mathrm{x}+18.631 & 47.44 \\ \text { Leaves NH } & \mathrm{y}=0.3793 \mathrm{x}-12.923 & 165.89 \\ \text { Leaves EA } & \mathrm{y}=0.7489 \mathrm{x}-1.9571 & 69.38 \\ \text { Leaves ME } & \mathrm{y}=0.8114 \mathrm{x}-4.5593 & 67.24\end{array}$

control $(\mathrm{IC} 50=98.38 \mu \mathrm{g} / \mathrm{mL})$. Leaves ME, leaves EA, and stem EA also give better activity of alpha glucosidase inhibitors than acarbose with IC50 value $67.24 \mu \mathrm{g} / \mathrm{mL}, 69.38 \mu \mathrm{g} / \mathrm{mL}$, and $72.85 \mu \mathrm{g} / \mathrm{mL}$, respectively. Stem NH and leaves $\mathrm{NH}$ had lower inhibitory activity than acarbose wit IC50 value $207.64 \mu \mathrm{g} / \mathrm{mL}$ and $165.89 \mu \mathrm{g} / \mathrm{mL}$. The regression equation and IC50 value showed in following table 5 .

Previous phytochemical study by Perez et al (2015), ethanol extract of $M$. peltata contained flavonoid, alkaloid, and tannin'. Many bioactive compounds from different plants have been reported to have hypoglycemic effect, in that mostly phenolics, resin glycosides, and flavonoids have a positive correlation as antidiabetic agents ${ }^{11}$. The ethanol extract shows greater inhibition activity in both stem or leaves of $M$. peltata compared to other extracts. The presence of flavonoids and phenolic compounds in ethanol extract of $M$. peltata may act against diabetes mellitus either through their capacity to avoid glucose absorption.

\section{CONCLUSION}

M. peltata has potential antioxidant and alpha glucosidase inhibitor activity for diabetic therapy. Antioxidant power of $M$. peltata extract had positive correlation in alpha glucosidase inhibitor activity. Stem ME has the best antioxidant and better alpha glucosidase inhibitor activity than acarbose as positive control. Phytochemical content of phenolics, resin glycosides, and flavonoids of the $M$. peltata extract had positive correlation of hypoglycemic activity and had proven as antidiabetic agent in previous study.

\section{ACKNOWLEDGEMENT}

We would like to acknowledge the financial assistance obtained from the "Publikasi Terindeks Internasional (PUTI) Q3 Grant" from Universitas Indonesia with contract number BA-1517/UN2.RST/ PPM.00.03.01/2020.

\section{REFERENCE}

1. Cosentino, Francesco, et al. 2019 ESC Guidelines on diabetes, prediabetes, and cardiovascular diseases developed in collaboration with the EASD: The Task Force for diabetes, pre-diabetes, and cardiovascular diseases of the European Society of Cardiology (ESC) and the European Association for the Study of Diabetes (EASD). European heart journal, 2020, 41.2: 255-323.
2. WHO Fact Sheet of Diabetes, 2016. https://www.who.int/newsroom/fact-sheets/detail/diabetes (Acces at 19 Feb 2020).

3. Whiting, David R., et al. IDF diabetes atlas: global estimates of the prevalence of diabetes for 2011 and 2030. Diabetes research and clinical practice, 2011, 94.3: 311-321.

4. Helvaci, Mehmet Rami, et al. Acarbose versus metformin in the treatment of metabolic syndrome. World Family Medicine Journal Incorporating the Middle East Journal of Family Medicine, 2018, 99.5833: $1-6$.

5. Aberg, J.A., Lacy, C., Amstrong, L., Goldman, M. and Lance, L.L., 2009, Drug Information Handbook 17th Edition, American Pharmacist Association.

6. Ratnadewi, Anak Agung Istri, et al. Revealing anti-diabetic potency of medicinal plants of Meru Betiri National Park, JemberIndonesia. Arabian Journal of Chemistry, 2020, 13.1: 1831-1836.

7. Tran, Ngan; Pham, Bao; Le, Ly. Bioactive compounds in anti-diabetic plants: From herbal medicine to modern drug discovery. Biology, 2020, 9.9: 252

8. Woerdenbag, Herman J., et al. Jamu: Indonesian traditional herbal medicine towards rational phytopharmacological use. Journal of herbal medicine, 2014, 4.2: 51-73.

9. Perez, Kristine Jay B., et al. Phytochemical and antibacterial properties of the ethanolic leaf extract of Merremia peltata (L.) Merr. and Rubus spp. Adv. Environ. Biol, 2015, 9.19: 50-56.

10. Djamaan, Akmal, et al. Extraction, fractionation and Cytotoxicity Test of Merremia peltata (L.) Merr.,(Fam. Convolvulaceae) Leaves. Der Pharmacia Lettre, 2016, 8: 48-52

11. B. Yuvaraj and M. Sathish, In vitro and in vivo antidiabetic activity on leaves of Merremia hederacea (Burm. f.) Hallier f. International Journal of Green Pharmacy (IJGP), 2019, 13.04.

12. Arunachalam, Karuppusamy; Parimelazhagan, Thangaraj. Antidiabetic activity of aqueous root extract of Merremia tridentata (L.) Hall. f. in streptozotocin-induced-diabetic rats. Asian Pacific journal of tropical medicine, 2012, 5.3: 175-179.

13. Gandhi, G. Rajiv; Sasikumar, Ponnusamy. Antidiabetic effect of Merremia emarginata Burm. F. in streptozotocin induced diabetic rats. Asian Pacific journal of tropical biomedicine, 2012, 2.4: 281-286.

14. Marchianti, Ancah Caesarina Novi, et al. Gel formulations of Merremia mammosa (Lour.) accelerated wound healing of the wound in diabetic rats. Journal of Traditional and Complementary Medicine, 2021, 11:38-45.

15. Burda, Stanislaw; Oleszek, Wieslaw. Antioxidant and antiradical activities of flavonoids. Journal of agricultural and food chemistry, 2001, 49.6: 2774-2779.

16. Wojdyło, Aneta; Oszmiański, Jan; Czemerys, Renata. Antioxidant activity and phenolic compounds in 32 selected herbs. Food chemistry, 2007, 105.3: 940-949

17. Elya, Berna, et al. Antidiabetic activity and phytochemical screening of extracts from Indonesian plants by inhibition of alpha amylase, alpha glucosidase and dipeptidyl peptidase IV. Pakistan Journal of Biological Sciences, 2015, 18.6: 279.

18. Albayrak, Sevil; Atasagun, Bayram; Aksoy, Ahmet. Comparison of phenolic components and biological activities of two Centaurea sp. obtained by three extraction techniques. Asian Pacific journal of tropical medicine, 2017, 10.6: 599-606.

19. Chemat, Farid, et al. Ultrasound assisted extraction of food and natura products. Mechanisms, techniques, combinations, protocols and applications. A review. Ultrasonics sonochemistry, 2017, 34: 540-560.

20. Wojcikowski, Ken, et al. Antioxidant capacity of 55 medicinal herbs traditionally used to treat the urinary system: a comparison using a sequential three-solvent extraction process. The Journal of Alternative and Complementary Medicine, 2007, 13.1: 103-110.

21. Blois, Marsden S. Antioxidant determinations by the use of a stable free radical. Nature, 1958, 181.4617: 1199-1200. 
22. Ozcelik, B.; Lee, J. H.; Min, D. B. Effects of light, oxygen, and pH on the absorbance of 2, 2-diphenyl-1-picrylhydrazyl. Journal of Food Science, 2003, 68.2: 487-490.

23. Njus, David, et al. Ascorbic acid: The chemistry underlying its antioxidant properties. Free Radical Biology and Medicine, 2020.
24. Apak, Resat; Capanoglu, Esra; Shahidi, Fereidoon (ed.). Measurement of Antioxidant Activity and Capacity: Recent Trends and Applications. John Wiley \& Sons, 2017.

25. Wakeel, Abdul, et al. Solvent polarity mediates phytochemical yield and antioxidant capacity of Isatis tinctoria. PeerJ Journals, 2019, 7: e7857.

\section{GRAPHICAL ABSTRACT}

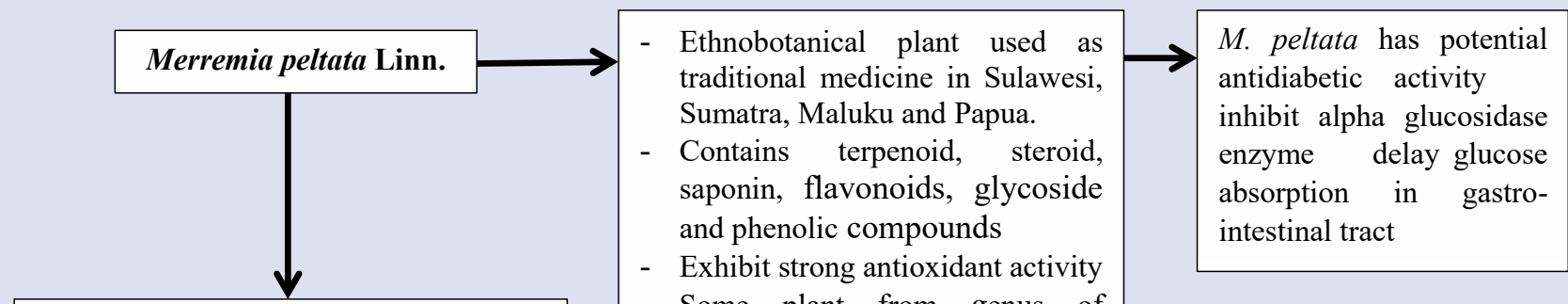

\section{Methode:}

- Extraction leaves and stems of $M$. peltata using Ultrasonic Assisted Extraction (UAE) with N-Hexane, Ethyl Acetate, and Methanol $96 \%$ as a solvent.

- Antioxidant screening using DPPH and FRAP method

- Measurement of alpha glucosidase inhibition of leaves and stems

\section{Conclusions:}

- UAE method successfully extracted active compounds from leaves amd stems of $M$. peltata.

- Antioxidant power of M. peltata extract had positive correlation in alpha glucosidase inhibitor activity.

- Methanol extract of M. peltata stem has the best antioxidant and better alpha glucosidase inhibitor activity (IC50 $=47.44 \mu \mathrm{g} / \mathrm{mL}$ ) than acarbose as positive control $(\mathrm{IC} 50=98.38 \mu \mathrm{g} / \mathrm{mL})$

- Phytochemical content of phenolics, resin glycosides, and flavonoids of the M. peltata extract had positive correlation of hypoglycemic activity and had proven as antidiabetic agent in this study.

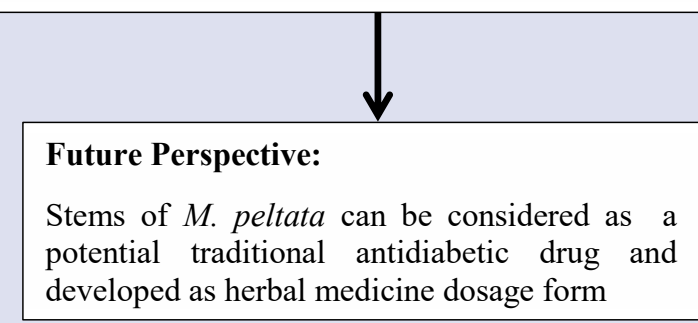




\section{ABOUT AUTHORS}

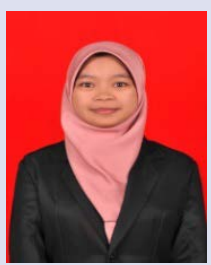

Bannan Muthiatul A is a Pharmacist and Magister Pharmacy Student at the Faculty of Pharmacy, Universitas Indonesia, Kampus UI Depok, West Java 16424, Indonesia. She conducted research on pharmacognosy study of natural product and biotechnology of pharmacy.

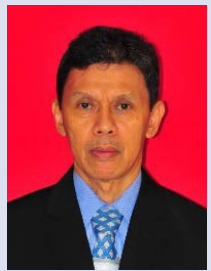

Muhammad Hanafi is a Researcher at the Research Center for Chemistry, Indonesian Institute of Sciences, PUSPITEK area, Serpong, South Tanggerang, Banten, Indonesia and Lecturer at the Faculty of Pharmacy, University of Pancasila, Srengseng Sawah, Jakarta, Indonesia. He has research experience in the field of Natural Product.

Berna Elya is a Professor and Lecturer at the Faculty of Pharmacy, Universitas Indonesia, Kampus UI Depok, West Java 16424, Indonesia. She develops works in the area of Pharmacognosy and Phytochemistry (Natural Product).

Cite this article: Afidah, Muthiatul B, Elya B, Hanafi M. Antioxidant and Alpha Glucosidase Inhibitor Screening of Merremia peltata L. as Potential Traditional Treatment for Diabetes Mellitus. Pharmacogn J. 2021;13(4):902-908. 